UNIO - EU Law Jounal. Vol. 3, No. 3, May 2017, pp 10-24.

®2017 Centre of Studies in European Union Law

School of Law - University of Minho

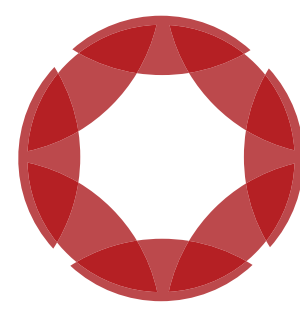

\title{
The dialectic relation between the national and the European constitutional identity in the framework of European Constitutional Law
}

\section{Francisco Balaguer Callejón*}

ABSTRACT: This article intends to reflect on the concept of constitutional identities of states in the frame of the dialectic relationship between the legal order of the European Union and the national legal orders. Both the conflictual dimension of the constitutional identity and the relations of confluence that that can maximize are explored. It concludes with an open and flexible understanding of the concept of constitutional identity which can benefit the evolution of the national constitutional law in an Europeist sense and the progressive transformation of the European legal system in a constitutional sense.

KEYWORDS: European Union - constitutional identity - interconstitutionality - European constitutional law. 


\section{Introduction}

The constitutional identity of States does not only present a conflictual slope, as the one that derives from considering it as "counter-limit", but it can also operate in relations of confluence, ${ }^{1}$ as it is shown by the Court of Justice of the European Union (CJEU) which incorporated internal constitutional law, while acknowledging its particularities, in the modulation of the application of European law.

What is at stake is the judicial application of the concept of identity, at the European level, that corresponds to the one that at the internal level, entails the possible integration of European law within the parameter of constitutionality. ${ }^{2}$ The constitutional identity term is used here in a broad or extensive sense to refer to the particularities of the constitutional systems of the States that are not necessarily part of the national identity in a strict sense, as essential or hard core, of the constitutional order. However, bearing in mind, and in that strict sense, that the national identity is a concept 'of border' that poses probably unsurmountable concretization problems and difficulties to take it operative as a legal concept judicially applicable, this other 'improper' dimension of national identity may fulfil it with content inserting it in a normalized relation of confluence among legal systems that deactivates the disruptive political potential of the European integration.

In any case, it is necessary to inform that overcoming the relation problems of the European legal system and the internal constitutional systems depends upon the existence of an authentic Constitution (unlike the Treaty establishing a Constitution for Europe, not even the Treaty of Lisbon) that makes possible the articulation of an European constitutional system in which the secondary constitutional systems, the ones of Member States, are fully integrated. Notwithstanding the fact that the European Union did not reach that primary constitutional level yet and it will neither achieve it with the Treaty of Lisbon, and even not knowing if it will take that step in a near future. One could wonder nonetheless, that the result would only be achieved in a limited manner, in the sense that the international constitutional European community will be, for a long time, a very plural community, and conditioned by strong asymmetries, which in turn will result in the impossibility of overcoming the constitutional tension in favour of the European dimension.

The difficulties posed in the current situation of the relations between internal and European do no emerge only from the non-primary nature of the European legal system. The debacle is, given the development of the European integration, not only that the European system is not primary, because it did not achieve that condition yet, but the internal system is not primary neither because of the increasing legal-political interdependence (not to mention economic) of the European system. We are therefore, faced with a transition period in which the internal legal systems lost their condition of primary legal systems (although they can recover it by triggering Article $50 \mathrm{TEU}$, as

\footnotetext{
${ }^{1}$ As pointed-out by A. Schillaci, the counter-limits may be nor only instruments of defence of the internal constitutional order but also "instruments of openness and mechanisms of material integration", in such a manner that "the reserves of constitutionality, until now identified as moments of relentless opposition, and internal aporia of the relations between systems end up becoming an instrument of guarantee and mechanisms of representation of the specific demands of each community". See A. Schillaci, "Caminos de la integración material: la comunitarización de los contralimites en la Decisión Sociéte Arcelor Atlantique et Lorraine del Conseil d'Etat", in Revista de Derecho Constitucional Europeo, No. 8, July-December 2007, http://www.ugr. es/ redce/REDCE8/articulos/12AngeloSchillaci.htm

2 See my essay "Primato del diritto europeo e identità costituzionale nell'esperienza spagnola", in the press in Italy.
} 
was the case with the United Kingdom following Brexit) and the European legal system did not acquire it yet. This period of transition sparks some of the legal problems that we face in the relations among the European legal system and the internal legal ones.

The key peculiarity of this articulation between internal and European systems in this transition period does not entail, however, relation problems that are, in fact, perfectly normal. The difficulties do not emerge from the existence of conflicts (that are inherent to the systems regardless of what type of system they are) but rather from the lack of cross-cutting rules, techniques and mechanisms that may overcome those conflicts in a satisfactory fashion for both parties. However, the absence of those rules cannot be addressed (at least considering the constitutional experience gathered so far) as long as this transition period is in place and the European legal system awaits shaping as a primary constitutional system from which the legal-constitution systems of Member States derive their legitimacy from (secondary therefore). Only then the always hard articulation between the European legal system and the internal ones can be pacified.

In the current state of affairs, one can only talk about the absence of rules that allow for the resolution of conflicts at the constitutional level since at the infraconstitutional level, those rules exist and were accepted by mainly all Member States. At the Constitutional level, however, the tension is unavoidable since the European Union did not incorporate, in its plenitude and in all its aspects, the European constitutional patrimony, namely pluralist democracy as well as the social dimension that - even if in an increasing formal configuration - it is still a structural element of that same patrimony.

\section{The European constitutional identity in the internal dialectics of the European Constitutional Law}

The dialectic relation among the European legal system and the internal ones does not reveal a conflictual profile through the counter-limits or the constitutional reservations that define a constitutional identity before European Law. One could say that that conflictual slope has meaning if the European Union acts outside the axiological frontiers of the European constitutional patrimony, this is beyond the constitutional identity defined by the European Constitutional Law. In this transition period, in which the EU does not have but a constitutional density analogous to those of Member States, that identity cannot only be the one of the European Constitutional Law in a narrow sense (the EU one) but rather in a broad sense (from the various constitutional spaces living side by side in the European space). ${ }^{3}$

When the dialectic relation between internal constitutional law and European law, it is within the margins of the European Constitutional Law (in a broad sense) and within the framework of a common and shared ${ }^{4}$ constitutional culture. It acquires a distinct nature, which is no longer conflictual but integrational and complementary. One must, therefore, on one side, differentiate the possible collision between European law and internal constitutional law and, on the other, the eventual integration of European

\footnotetext{
${ }^{3}$ About this disctinction, my work "Perfis metodológicos do Direito Constitucional Europeu", in O constitucionalismo do séc. XXI na sua dimensão estadual, supranacional e global, Vasco Pereira da Silva y Francisco Balaguer Callejón (coords.), (Lisboa:Instituto de Ciências Jurídico-Políticas da Faculdade de Direito da Universidade de Lisboa, 2015) 19-20.

${ }^{4}$ In similar terms to what Peter Häberle would define as the "European common constitutional law". See P. Häberle, “Gemeineuropäisches Verfassungsrecht”, EuGRZ (1991), Spanish version by Emilio Mikunda, "Derecho constitucional común europeo”, No. 79, REP (1993).
} 
Union law in the internal parameter of constitutionality. This does not represent a conflict between that parameter and constitutional law but, their confluence to determine the constitutionality or unconstitutionality of infra-constitutional law.

The ordinary perception regarding constitutional control is the direct contrast between an infra-constitutional norm and a constitutional one. This contrast may determine itself the unconstitutionality of the norm that was the object of constitutional control in a way that the parameter of constitutionality may be only composed by constitutional norms. This perception results incomplete, however, since to the direct control one can add the designated control which happens when, following the constitutional norms, one must integrate the parameter of constitutionality of infraconstitutional norms (the so called "brought norms" according to Italian doctrine) that have the same value of the ones that will be controlled. This set of norms integrates the so-called "constitutional block" in Spain 5 and shall be object of consideration by the public powers when, through these rules, at stake is the attribution of competences or proceedings that determine its legal production.

Notwithstanding the manifest heterogeneity in the possible content of the constitutionality block means there is a common element to all possible prerequisites: the one that relates to the condition of the norms on legal production that integrate, and through which we can determine the validity of other norms, that have the same value nonetheless. There is not necessarily a legal hierarchy between the parametric norms and the controlled ones. On the contrary, it is the competencies principle the ultima ratio justification of this function: these are norms that enable or modulate competencies (normative faculties) attributed to certain organisms. They carry out, therefore, the material constitutional function, ${ }^{6}$ the one of regulating the processes of legal production. The material function, however, that does not reflect its complex position within the system of sources of law.

The constitutional block presents positive aspects regarding the flexibility with which it enables the legal system, particularly in a situation where there is a plurality of systems. The conflicts among legal systems shall be solved in line with the competencies criteria that may be adjusted considering the diversity of infra-constitutional norms that integrate the parameter of constitutionality. From that perspective, the constitutional block presupposes a certain openness to the constitutional necessities at the legislative level and in the relations among the territorial powers.

In what concerns European law, the problem arises whether the European norms may also be part of the constitutional block or, in a broader sense, in the parameter of constitutionality. The Spanish Constitutional Court responded negatively to this question by considering that European law is not part of the constitutional block and cannot be incorporated into the parameter of constitutionality. The Court followed a cautious jurisprudential line to avoid being faced with questions arising from the application of European law. For that end, it conferred infra-constitutional character to these types of questions when, in fact, they have a constitutional nature considering that any violation of valid European law implies, necessarily, the violation of the legal basis

\footnotetext{
${ }^{5}$ In Spain, this concept applies to the relations between the State's legal system and the regional ones, as prescribed by Article 28, recital 1, LOTC: «Para apreciar la conformidad o disconformidad con la Constitución de una Ley, disposición o acto con fuerza de Ley del Estado o de las Comunidades Autónomas, el Tribunal considerará, además de los preceptos constitucionales, las Leyes que, dentro del marco constitucional, se hubieran dictado para delimitar las competencias del Estado y las diferentes Comunidades Autónomas o para regular o armonizar el ejercicio de las competencias de éstas».

${ }^{6}$ See F. Rubio Llorente, “El bloque de constitucionalidad”, in REDC, n. 27 (1989), 25.
} 
prescribed by Article 93 of the Spanish Constitution (SC), which opens the internal legal system to European Law. ${ }^{7}$

Now, this constitutional nature, resulting from Article $93 \mathrm{SC}$, does not require that it is the Constitutional Court to intervene in the resolution of conflicts between European law and internal law (albeit that intervention may take place when a lesion of other constitutional norms occurs: see the Spanish Constitutional Court's Judgments SSTC 58/2004 and 194/2006). That intervention would only be necessary if the relations between both legal systems were governed by a principle of hierarchy that would determine the nullity of internal norms that were in contradiction with European ones. However, the principle of primacy of EU law implies only putting aside the internal norm and the application of the European preferential: what is at stake is a matter of efficiency and not one of normative validity, which must be dealt with by the ordinary judge.

Beyond these technical questions, it is certain - despite the doctrine of the Spanish Constitutional Court - that EU law is integrated in the Spanish legal system and this triggers an interaction between it and the European one, which will impact on the constitutional level as well. This incidence will progressively increase in close relation with the intensification of the integration process and to deny the problem - as the Spanish Constitutional Court does - will not help to put forward a solution and neither to control its effects.

An important novelty in relation to the possible integration of European law in the parameter of constitutionality is the Judgment of the Spanish Constitutional Court 86/2011, 9 of July, in which the Full Court referred three questions for preliminary ruling that would be answered by the CJEU in the Melloni's Judgment (Case C-399/11). The Spanish Constitutional Court acknowledged that European Law can integrate the canon of constitutionality, by highlighting in point FJ4.B) that: "regarding the appeal this Court faces a problem for which solution largely depends on the interpretation and validity of the Framework Decision 2002/584/JAI, from the Council, 13 of June, as well as on the interpretation of Article 53 of the Charter of Fundamental Rights of the European Union (CFREU) and the consequences that result from that norm", since the "parameter of control that we shall apply $(. .$.$) must be integrated, among others, from the rules of EU law that protect$ the correspondent fundamental rights as well as the ones that regulate the European Arrest Warrant". It was predictable, therefore, that a substantive overturn of the doctrine followed until now. It was not the case, however, as the Judgement 26/2014, 13 of February 2014, shows the when answering the main question in the proceedings, arguing that European law is to be considered as interpretative criteria, leads us to Article 10 paragraph 2 SC and not to the direct applicability of EU law as part of the parameter of constitutionality.

\section{National Constitutional identity and relations of confluence of the European validity parameter}

In the same way that European constitutional law may be linked to the constitutional level of internal law incorporating itself in the parameter of

\footnotetext{
${ }^{7}$ According to Article 93 SC: "Mediante ley orgánica se podrá autorizar la celebración de tratados por los que se atribuya a una organización o institución internacional el ejercicio de competencias derivadas de la Constitución. Corresponde a las Cortes Generales o al Gobierno, según los casos, la garantía del cumplimiento de estos tratados y de las resoluciones emanadas de los organismos internacionales o supranacionales titulares de la cesión".
} 
constitutionality, - and limiting the decisions of the Constitutional Court that must decide upon the validity of internal norms -, internal constitutional law has developed an analogue function regarding the activity of the CJEU. This is the consequence of the incorporation of Article 4 paragraph 2 TEU concerning the respect of the Constitutional identities of the Member States. It is, however, undeniable that this version of "constitutional identity" has very little to do with idea of "counter-limits", i.e., with the existence of an essential core of the internal constitutional system that could not be touched by European law.

On the contrary, what is at stake is a similar mechanism to the "margin of appreciation" that appeals to the constitutional identity "with lowercase letter", as Pedro Cruz Villalón affirms, which entails the loss of its absolute character. Thereby, "the constitutional identity may be invoked, with very limited reservations, by the Member States, with the cost of having to compete with a plurality of categories and, in particular with a proportionality assessment' ${ }^{8}$ As Stelio Mangiameli maintains; "the limitations imposed to the application of some European law rules are a consequence of the systematic interpretation of the supranational law itself, in relation to which the norms from the national Constitutions are assumed not by their normative reach but as a part of the relevant facts for the application of European principles, even when those correspond in terms of content to concepts used by the national constitutional norms".?

We could therefore, affirm that the CJEU does not apply the counter-limits here as such, not even in a "Europeanised" slope because, in fact, it does not define the constitutional identity as such, but only to what extent certain particularities of the constitutional system might module the application of European law. These particularities are, necessarily, an integral part of the "constitutional identity" is more than debatable. This does not mean that they may not be so (for example, in the case of the principle of human dignity, in Germany) but that that condition is not relevant for the CJEU since, even if they were not part of the "constitutional identity", they could be used to modulate the application of the principle of primacy.

In the Judgment Omega, the CJEU recalls the "margin of appreciation", saying that the competent national authorities must decide within the limits imposed by the Treaties when there is an exception to public order capable of justifying restriction on the freedom to provide services since "the specific circumstances which may justify recourse to the concept of public policy may vary from one country to another and from one era to another". ${ }^{10 / 11}$ From this perspective, the question is solved integrally within the framework of European law since, as the Court states; "there can therefore be no doubt that the objective of protecting buman dignity is compatible with Community law, it being immaterial in that respect that, in Germany,

\footnotetext{
${ }^{8}$ See P. Cruz Villalón, "La identidad constitucional de los Estados miembros: dos relatos europeos", in Scritti in onore di Antonio D'Atena, (Roma: Giuffrè Editore, 2015), Tomo I, 739, 742. See also, A. Ruggeri, "Primato del diritto sovranazionale versus identità costituzionale? (Alla ricerca dell'araba fenice costituzionale: i "controlimiti")": www.forumcostituzionale.it/wordpress/wp-content/.../ ruggeri.pdf and S. Gambino, "Identidad constitucional nacional, derechos fundamentales e integración europea" in Revista de Derecho Constitucional Europeo, No. 18, Julio-Diciembre (2012): http://www.ugr.es/ redce/REDCE18/articulos/02 GAMBINO.htm.

9 S. Mangiameli, "L'Unione Europea e l'identità degli Stati membri", in Scritti in onore di Antonio D'Atena, Tomo III, Giuffrè Editore (2015) 1839.

${ }^{10}$ This is so, although the CJEU acknowledges also that "according to the referring court, the probibition on the commercial exploitation of games involving the simulation of acts of violence against persons, in particular the representation of acts of homicide, corresponds to the level of protection of buman dignity which the national constitution seeks to guarantee in the territory of the Federal Republic of Germany". (Recital 39, Judgment Omega, Case C-36/02, 2004).

${ }^{11}$ Judgment Omega, Case C-36/02, 2004, recital 31.
} 
the principle of respect for human dignity has a particular status as an independent fundamental right". ${ }^{12 / 13}$ We shall remind that the Judgment Omega was issued in 2004 and the Treaty of Lisbon was not into force yet, and therefore the clear recognition of the principle of constitutional identity, pursuant to Article 4 paragraph 2 TEU, was neither so. ${ }^{14}$

The CJEU decision in Ilonka Sayn-Wittgenstein from 2010, is subsequent to the entry into force of the Lisbon Treaty. Indeed, the Austrian government argues its constitutional identity precisely, saying; "that the provisions at issue in the main proceedings are intended to protect the constitutional identity of the Republic of Austria". "This mention is made, however, in a peculiar manner since it recognizes that it is not an element of the republican principle but a pretension to guarantee the formal equality. The CJEU acknowledges that "in the context of Austrian constitutional history, the Law on the abolition of the nobility, as an element of national identity, may be taken into consideration when a balance is struck between legitimate interests and the right of free movement of persons recognised under European Union law", ${ }^{16}$ wherefore "the justification relied upon by the Austrian Government by reference to the Austrian constitutional situation is to be interpreted as reliance on public policy". ${ }^{17}$

The reasoning of the CJEU, after insisting on the idea that the competent national authorities shall have a "margin of appreciation", is sufficient evidence to decide, within the limits set out by the Treaty, whenever there is an exception of public order, resorting to the key question of equality, the one that permits the resolution of a problem in the way that the Court does, even when invoking the constitutional identity norm, Article 4 paragraph 2 TEU. In the context of the main proceedings, the Austrian Government has stated that the Law on the abolition of the nobility constitutes implementation of the more general principle of equality before the law of all Austrian citizens. The European Union's legal system undeniably seeks to ensure the observance of the principle of equal treatment as a general principle of law. That principle is also enshrined in Article 20 of the Charter of Fundamental Rights. "There can therefore, be no doubt that the objective of observing the principle of equal treatment is compatible with European Union law". ${ }^{18}$ Finally, "it does not appear disproportionate for a Member State to seek to attain the objective of protecting the principle of equal treatment by probibiting any acquisition, possession or use, by its nationals, of titles of nobility or noble elements which may create the impression that the bearer of the name is holder of such a rank.". ${ }^{19}$

Lastly, in Comission v. Spain, Case C-151/12, 24 October 2013, the CJEU made reference to a relationship mechanism between the State's legal system and the regional ones when, in fact, that mechanism is not definitely part of the Spanish constitutional identity, as the rule on the subsidiary nature of the State law regarding regional law.

\footnotetext{
${ }^{12}$ See on Judgment Omega, S. Sánchez Lorenzo, "Derechos fundamentales y libertades de circulación a la sombra de una Constitución para Europa: Comentario a la Sentencia TJCE (Sala 1. ${ }^{\mathrm{a}}$ ), de 14 de octubre de 2004 (Asunto C-36/02: “Omega")", in Revista de Derecho Constitucional Europeo, No. 5, January-June 2006, http://www.ugr.es/ redce/REDCE5/articulos/14sixtosanchezlorenzo.htm

${ }^{13}$ Judgment Omega, Case C-36/02, 2004, recital 34.

${ }^{14}$ This is so, although the CJEU acknowledges also that "according to the referring court, the probibition on the commercial exploitation of games involving the simulation of acts of violence against persons, in particular the representation of acts of bomicide, corresponds to the level of protection of buman dignity which the national constitution seeks to guarantee in the territory of the Federal Republic of Germany" (Recital 39, Judgment Omega, Case C-36/02, 2004).

${ }^{15}$ Judgment Ilonka Sayn-Wittgenstein, Case C-208/09, 2010, recital 74.

${ }^{16}$ Idem, recital 83.

${ }^{17}$ Ibidem, recital 84.

${ }^{18}$ Ibidem, recital 88 and 89.

${ }^{19}$ Ibidem, recital 93.
} 
Moreover, the CJEU analysis of the interpretation to be given by Spain to this clause, using a correct criteria, in our view, is based on the case law of the Spanish Constitutional Court: "it must be noted that, in accordance with the case-law of the Tribunal Constitucional (Constitutional Court), which the Kingdom of Spain cites in its observations, Article 149(3) of the Constitution does not appear to permit the application of national rules in a supplementing manner in the absence of legislation by the Autonomous Communities, but only to fill identified gaps. It is appropriate to add that, at the hearing, the Kingdom of Spain confirmed that, in the present case, the Autonomous Communities, with the exception of the Autonomous Community of Catalonia, have not exercised their legislative powers. In those circumstances, the application of the supplementing clause in the present case would not be appropriate as regards the intracommunal river basins outside Catalonia"."20

In fact, in this case, Spain invoked Article 4 paragraph 2 TEU combined with Article 288 TFEU to reproach the Commission for trying to impose the way in which the Directive should be transposed, since it understood that the subsidiarity clause of the State law, in the terms of Article $149^{\circ}$ paragraph 3 of the Spanish Constitution, was enough to ensure the application of European law. Thus, here it is not the case of any matter of constitutional identity as it was the case in the various proceedings mentioned before. However, the important aspect of this case-law from the CJEU is the integration of the concept of constitutional identity itself (even if in an "improper" fashion) and, therefore, the integration of internal constitutional norms in the parameter mobilized to assess its validity, even if those are not exactly part of the constitutional identity of States. This way, a confluence between constitutional law and European law to assess validity questions regarding norms that take place also at the internal level occurs by means of the possible integration of the European law in the parameter of constitutionality.

The dialectic relation between the national constitutional identity and the European one acquires, therefore, a double perspective. On one side, the incorporation of European law in the internal parameter of constitutionality, contributes to reconfigure the "national constitutional identity" in a broader sense. On the other, the function that state constitutional law (the national constitutional identity in a broad sense) plays in modulating the application of European law contributes to reconfigure the specific European constitutional identity of the Union, since it defines its possibilities, its limits and its developing lines, in the confrontation of the national constitutional law.

\section{The national constitutional identity and its conflictual dimension}

In what concerns the relations of conflict between European law and internal law, one must acknowledge that the primacy of EU law does not refrain before internal constitutional law. It does not differentiate, to this end, the distinct levels of State law. Moreover, it does not comprehend, even, mechanisms that make possible, in the internal order, to conceal the observance of European law with the constitutional law demands that require a specific revision mechanism to modify the constitutional norms which are contradictory with the due immediacy of the application of European law.

The normativity of the Constitution is the result of a long and hard historical process that was a much-desired outcome by the European nations, and so is the European integration process, because it facilitates the establishment of a peaceful and

${ }^{20}$ Judgment Comission v. Spain, Case C-151/12, 2013, recital 35. 
orderly co-existence that respects pluralism and guarantees the fulfilment of rights and liberties. It is not difficult to understand, from that perspective, the perplexity with which both constitutionalists and citizens follow a process that, since it did not reach its highest development phase, relativizes, and puts in question the normativity of the Constitution, without offering a proper constitutional system in which the constitutional feeling of European citizens can be deposited and that answers to the same pleas that the internal systems are faced with today.

This perplexity is shared by the constitutional courts of Member States, namely the Spanish Constitutional Court, that fulfilling its obligation of the ultimate guarantor of the Constitution, clearly established the principle according to which the application of European law cannot be done against Constitutional norms, because the European integration does not diminish the binding of public powers to the Constitution. The doctrine is very clear on this point. In STC 64/1991, it is expressly highlighted that $\mathrm{t}^{21}$ "the concession of the exercise of competences in favour of supranational entities does not imply that the internal authorities are no longer abided by the internal legal system, when they act in the fulfilment of obligations resulting from those entities, since in these cases what is at stake is also public power that is therefore subject to the Constitution and to the Spanish legal system (Article 9 paragraph 1 Spanish Constitution)". This general principle presupposes that all the procedural rules linked to constitutional proceedings connected to the action of Spanish public powers are open, even when these actions are necessary or derive from the application of european law. ${ }^{22}$

In the Spanish constitutional jurisprudence, the question of the possible constitutional conflict was raised again, on the occasion of the ratification process of the Draft Constitutional Treaty, due to the express recognition of the principle of primacy that was made by Article I-6 in which "[t] he Constitution and law adopted by the institutions of the Union in exercising competences conferred on it shall have primacy over the law of the Member States." This norm, withdrawn with the Treaty of Lisbon (since the principle of primacy is now enshrined in the Declaration No 17 annexed to the Final Act of the Lisbon Treaty IGC), had raised concerns with its possible contradiction with Article 9 paragraph 1 Spanish Constitution ("Citizens and public authorities are bound by the Constitution and all other legal provisions"). This question was raised by the Council of State in its diktat on the Treaty establishing a Constitution for Europe, suggesting that the Government would use the mechanism, via Article 9 paragraph 5 Spanish Constitution, to initiate proceedings to assess the constitutionality of this Treaty before the Spanish Constitutional Court. The Court replied to that request with the Declaration 1/2004, December 13, stating that there was not any contradiction between the Spanish Constitution and the Draft Constitutional Treaty.

The Court keeps in line, with this Declaration and with the previous doctrine, in the sense that the possible contradiction between European law and the Spanish Constitution would force a ruling from the Court: "In the unlikely case that the ulterior dynamics of EU law would lead to make this branch of law irreconcilable with the Spanish Constitution, - without the bypothetical excesses of European law in relation to its own (European)

\footnotetext{
${ }^{21}$ Judgment STC 64/1991, Spanish Constitutional Court, [FJ 4.b)].

22 Judgment STC 64/1991, Spanish Constitutional Court, FJ 4.a), the court indicates such concerning the writ of amparo: «es claro también que, en la medida en que se impugne en amparo un acto del poder público que, habiendo sido dictado en ejecución del Derecho comunitario europeo, pudiera lesionar un derecho fundamental, el conocimiento de tal pretensión corresponde a esta jurisdicción constitucional, con independencia de si aquel acto es o no regular desde la estricta perspectiva del ordenamiento comunitario europeo, y sin perjuicio del valor que éste tenga a los efectos de lo dispuesto en el artículo 10.2 SC».
} 
Constitution being dealt by ordinary mechanisms there enshrined - the conservation of the sovereignty of the Spanish people and the supremacy of the Constitution could lead this Court to approach the problems that from that case could arise, and that from the current perspective are inexistent, through the relevant constitutional mechanisms; furthermore, the protection of the said sovereignty is safeguarded by Article I-60 of the Treaty, a true counterpoint to Article I-6, permitting to define its real dimension: the primacy proclaimed in Article I-6 is incapable of surmounting the possibility of withdrawal that it is reserved to the sovereign, supreme will of Member States".2.

The Europeanisation of the counter limits by Article 4 paragraph 2 TEU, modified by the Treaty of Lisbon, implies the recognition by the Union of the existence of a constitutional core integrated by the fundamental political and constitutional structures of the Member States that must be preserved. The ground for a latent conflict in the constitutional front between the Member States and the European Union, that suggests the possible relativism of the principle of primacy, is now open. It is not, however, a question free from issues, since the proper existence of the Union as an autonomous legal system is dependent on the principle of primacy. For that reason, the constitutional conflict still lacks an easy solution. On the other hand, in order for that conflict to occur, is necessary that the conditions that could justify it take place, which is not the case in the first decision issued by a constitutional court of a Member State (Constitutional Court of the Czech-Republic, 31 January 2012) that ruled a legal act from a European entity ultra vires, by considering that the previous ruling of the CJEU (Judgment Landtová, Case C-399/09, 22 June 2011) went beyond the competences transferred to the EU by the scope of Article 10.a) of the Czech Constitution.

It is in any case evident that what we face here it is a possible contradiction that, until now, has no solution through the mechanisms established so far to articulate the European and internal systems. This contradiction is unsurmountable due to the transition period that the European integration process currently faces and until the creation of a Constitution of the Union to which the constitutional norms of the Member States are subject to. Despite the advance that the Treaty of Lisbon enshrines the configuration of the European constitutional law as "supreme law", proper of a Federal system, remains. In this future phase, it will not be possible to oppose the unconstitutionality of European law to the internal Constitution because the internal constitutional courts will be European tribunals as well and, therefore, will have the obligation to apply first the European Constitution over the internal one. There will be a "stronger linkage", in the terms defined by North-American federalism, between the internal constitutional courts and the European constitutional system, stronger than the one that exists in relation to the internal constitutional system.

In any way, as we could gather so far, it is necessary to distinguish between the conflictual dimension and the dimension of confluence of constitutional identity, both being able to be framed within the scope of Article 4 paragraph 2 TEU. The first do with the counter-limits, with the idea of a constitutional core potentially resistant to the idea of primacy. The second, however, is linked with the use that the CJEU has been making of the internal constitutional singularities of the Member States (defined now as the "constitutional identity") to modulate the application of the principle of primacy.

This European jurisdictional slope of the constitutional identity in the application that the CJEU has done of Article 4 paragraph 2 TEU may be framed,

\footnotetext{
${ }^{23}$ Declaration 1/2004, Spanish Constitutional Court, December 13, FJ 4.
} 
as we see, within the relations of confluence among legal systems, in the dialectic relation between European constitutional law in a strict sense (from the EU) and in a broad sense (including the national constitutional systems as well). This way, the national constitutional identity operates as a qualified element in the construction of the normative sense of the European norm, that could have a distinct reach if the interpreter would not have the express mandate to consider, precisely, the internal constitutional identity.

A confluence that shows, likewise, on the other side, via the possible incorporation of European law in the internal parameter of constitutionality, when that is proceeding, conforming therefore the other slope of the dialectic relation between the national constitutional law and the Union's, in the framework of European constitutional law. In any case, it is the European law that contributes to reconfigure the national constitutional identity in a broad sense.

The conflictual dimension of the constitutional identity, on the contrary, refers to counter-limits to identify - a constitutional core eventually resistant to European law, because it would define the constitutional identity of the State in a strict sense. It is here that problems of potential tension between European law and internal law occur, and where we should seek to value the content of the constitutional identity in a way that allows the recognition of its condition as "concept of boarder" that shall operate only as last result measure, when the conflict between European law and internal constitutional law is unsurmountable.

The characterization of what might be considered as an integral part of the "constitutional identity" of a State, in that strict sense, is not easy. At stake is a concept that appeals to a minimum from which there is no derogation possible, reminding us other similar notions that, in the Constitution of pluralism, refer to arbitral spheres to characterise what permits to recognise a right (the guarantee of the essential core of human rights) or an institution (the constitutional guarantees) as such. However, those arbitrators do not exist in the relation between European law and internal law, because neither the CJEU nor the internal constitutional courts may have a last say beyond their specific scope of decision (European law and internal constitutional law, respectively). From this perspective, the CJEU cannot define the ultimate meaning of constitutional identity, since, as we saw, it only resorts to it instrumentally as an extra factor to consider in the modulation of the application of the principle of primacy. However, it can neither attribute to the other part, the internal constitutional court, that function because the constitutional identity is a boarder-concept and boarders cannot be defined by only one of the parties. The constitutional courts can characterise the constitutional identity for internal purposes but cannot have the pretension of deciding the scope that that definition will have at the European level, in accordance with Article 4 paragraph 2 TEU.

Indeed, and considering that the constitutional identity regards the national Constitution that may have as "supreme interpreter", an internal constitutional system that has the last word, it is also certain that, since it can operate as a limit to the principle of primacy, it also implies an interpretation of the scope of European law, which is an attribution of the CJEU. In this way, there is not an unequivocal answer to this question. Therefore, there is not a single jurisdictional entity that may establish the last meaning of constitutional identity as the essential core of the internal legal-constitutional system. 


\section{Flexibility and convergence between the national constitutional identity and the European one. The example of Portugal}

The concept of national constitutional identity, in a strict sense, is linked to other national sovereignty concepts such as the primary constituent power, material limits and constitutional revision power. However, these concepts are precisely the ones that most harm suffered due to the process of supranational integration. The supranationally integrated national State is no longer sovereign at the external level (it was neither so before, at the internal level, with the adoption of a normative Constitution) and it is not equipped with a primary constituent power as long as it is a member of the European Union. The supranational integration resulted in an inevitable fragmentation of the constituent power ${ }^{24}$ that must be acknowledged while carrying the analysis of the concept of constitutional identity.

The nexus between the concept of constitutional identity, the constitutional revision, and the constituent power places us in a field particularly sensitive and unstable because the idea of constitutional identity is, to some extent, incoherent when considering the possibility of constitutional revisions that inevitably result in the transformation of the Constitution and, therefore, the constitutional identity. The existence of material limits of revision can neither be considered as an unsurmountable obstacle to the constitutional mutation that defines an essential core resistant to European law. Firstly, because in several European systems there are no stony clauses, and there are even specific provisions on "total revision" of the Constitution, as it is the case of Spain. But, mainly, because a democratic system cannot give away the legitimate constituent power to endow itself with a new constitutional order.

It is surprising, concerning this issue, the position adopted by the German Constitutional Court in Lisboa regarding a possible federal advance of the European integration. Firstly, the material limits of revision are an entity of the national State, aimed at preventing democratic regressions that have no place in a Member State of the European Union. Secondly, the German unification operated in the framework of the German Basic Law, although that implied not less than a modification of the constituent subject without following the procedure set out by Article 146 of that Basic Law, to provide the recently united German people with a new Constitution ("Verfassung").

The Portuguese system offers a very important reference to the actual debate on the concept of constitutional identity, in itself, regarding the process of European integration and Article 4 paragraph 2 TEU. The Portuguese Constitution offers a very relevant example of the relation between Constitutional revision and constitutional rupture. The modifications introduced by the subsequent amendments had a wide reach but the Portuguese constitutionalists do not doubt that the Constitution of 1976 is still alive because it keeps the core of basic principles that a Constitution to keep its Constitutional identity. The Portuguese Constitution is a complex work resulting, textually, of a constituent process prolonged in time, with important

\footnotetext{
${ }^{24}$ See my work, "El status constitucional de la reforma y la fragmentación del Poder Constituyente", in AAVV, La democracia constitucional. Estudios en homenaje al Profesor Rubio Llorente, Congreso de los Diputados, Tribunal Constitucional, Vol. I, Madrid (2002) 99-130 and "European Integration and Limitation of the Power of Constitutional Reform", in Limitations of National Sovereignty through European Integration, ed. Rainer Arnold (New York: Springer, 2016), 15-25.
} 
revisions that did not transform the Portuguese constitutional identity, as states Jorge Miranda, ${ }^{25}$ but rather, completed and fulfilled the constitutional consensus, as Gomes Canotilho affirms since the structural principles (rule of law, democracy, solidarity) and the fundamental rights that characterise the constitutional text, the identity of the Constitution. ${ }^{26}$ In the words of the previous President of the Constitutional Court, Professor Cardoso da Costa, we could talk about a "global constituent process" through which a constitutional document stabilized in its characterizing elements was gradually carved. ${ }^{27}$

This admirable lesson from the Portuguese constitutionalism teaches us something very important: Constitution and democracy do not have the same extension, democracy is more broad than the Constitution and shall remain open to the possibility of revision and change. With the condition, naturally, that what is in place is a pluralist democracy in which the essential principles of the constitutional democracy are safeguarded: Rule of law, controlling majority, protection of minorities, guarantee of fundamental rights.

This question inevitably leads us to the debate on the concept of constitutional identity that takes place today in Europe involving the constitutional national courts, the CJEU itself, and European scholars. As mentioned, not all Constitutions include material limits of revision and it is difficult to articulate within those a definition of constitutional identity. In the Portuguese case, the Constitution has a wide catalogue of contents protected by the "stony clauses" (Article 288 Constitution of the Portuguese Republic), but it is also the Constitution in which the norm on the material limits of revision, through a reform of previous Article 290, was modified, without this change affecting the constitutional identity.

Therefore, if the constitutional identity in its conflictual dimension assumes the existence of an inalienable essential core of the Constitution, but the Constitution admits its complete revision, as is the case in Spain, or made possible the incorporation of a new constituent subject without modifying its identity, as was the case in Germany, or modified its own revision limits, as happened in Portugal, in fact, what is the constitutional identity of these countries? In my view, the constitutional identity that can be opposed to European integration shall necessarily acknowledge this same openness of the constitutions to revisions or transformation of the constitutional system within a democratic context.

From this perspective, we shall consider, as mentioned before, that pluralist democracy and Constitution do not have the same extension always, because democracy is always wider than the Constitution. What the constitutional order must guarantee is the democratic freedom of expression, understood in the terms of pluralist democracy (with the necessary respect for minorities and the possibility of

\footnotetext{
25 "After seven constitutional revisions, after the Portugal's accession to the Communities and to the European Union, and after so many transformations in the country and the world, the Constitution is still the same Constitution that in 1976 was approved by the Constituent Assembly - because a Constitution is, and this cannot be emphasised strongly enough, more a set of principles and less a set of provisions." J. Miranda, "A originalidade e as principais características da Constituição Portuguesa”, in Cuestiones Constitucionales, No. 16, January - June 2007, p. 278.

${ }^{26}$ See J. Gomes Canotilho, Direito Constitucional e Teoria da Constituição, $3^{\mathrm{a}}$ Ed., (Coimbra: Almedina, 1998), 203 and ff. "Considered globally, the constitutional compromises made possible a constitutional project that has been reasonably capable of solving the problems raised by the political pluralism, by the social complexity and the conflictual democracy. This is the dynamic character that is it the base of the compromises achieved in the revision sphere". ${ }^{27}$ See J. Cardoso Da Costa, Prólogo a Javier Tajadura Tejada (Coord.) in La Constitución portuguesa de 1976: Un estudio académico treinta años después (Madrid: CEPC, 2006), XX.
} 
reversion of political options to make alternative governance possible). It is precisely the pluralist democracy that may be essentially identified with the constitutional identity and contrarily to concrete contents of the legal-constitutional system that mark the border of constitutional identity, in light of a European law that, in principle, shares these values and must safeguard them within the European Union, even when regressionist attitudes from Member States take place. ${ }^{28}$

Beyond the potential conflictual dimension of the national constitutional identity, we can also extract from the Portuguese Constitutional system, a relevant criterion regarding the convergence between the national constitutional identity and the European common identity. We can find it in the doctrine of the Portuguese Constitutional Court regarding the measure taken to tackle the economic crisis adopted to apply European policies. Indeed, the Court established a criterion that I think particularly relevant regarding the necessary accordance between European law and internal constitutional law considering the essential core of principles that configure the rule of law, in terms of the European common constitutional patrimony.

This way, the constitutional principles that the Court uses to declare the unconstitutionality of those measures are considered, also, as principles that bind in the same way the European Union: "for that matter, in this domain, there is no divergence between EU law and Portuguese Constitutional law. Indeed, the constitutional principles of equality, proportionality, and protection of legitimate expectations that have served as parameters, for the Constitutional Court, to assess the constitutionality of the national norms on issues like those brought by these proceedings, are part of the hard-core of a rule of law, integrating the European common legal patrimony to which the Union is also subject to". ${ }^{29}$

In short, it is necessary to appeal to the flexibility of the national conflictual identity, in the tension with the European constitutional identity, within the framework of European Constitutional law, to avoid the occurrence of artificial conflicts between the internal legal system and the European one, based on a rigid understanding of the concept of constitutional identity. The Europeist protection of the internal constitutional systems shall not have the additional limits of the internal ones: only the ones of the pluralist democracy.

The dialectic interaction between the national constitutional identity and the European one, in the framework of European Constitutional Law (this is, between its strict and broader sense) is also a factor of common identity development that

\footnotetext{
${ }^{28}$ Something that is has not be done effectively in practice, if we consider the case of Poland and Hungary, A different issue, that we cannot develop here, is if the constitutional identity of some Member States, as it is the case of Portugal, Spain, Italy or Greece was respected by the European entities since the economic crisis started. This is, if we can still talk about of an authentic pluralist democracy in the context of an economic interpretation of the Constitution that was imposed all over Europe, and to which a constitutional interpretation of the crisis shall have been opposed to. See, on this issue, my work, "El final de una época dorada. Una reflexión sobre la crisis económica y el declive del Derecho constitucional nacional", in Estudos em Homenagem ao Professor Doutor José Joaquim Gomes Canotilho, Constituição e Estado: entre Teoria e Dogmática, Vol. II, (Coimbra: Coimbra Editora, 2012) 99-122. And "Crisi economica e crisi costituzionale in Europa" in KorEuropa, No. 1/2012, "Crise économique et crise constitutionnelle en Europe", in Constitutions: Revue de droit constitutionnel appliqué, April-June 2013, "Crisis económica y crisis constitucional en Europa", in Revista Española de Derecho Constitucional, No. 98, May/August 2013 and also "Una interpretación constitucional de la crisis económica”, in Revista de Derecho Constitucional Europeo, Year 10, No. 19, January-June 2013, http://www.ugr.es/ redce.

${ }^{29}$ Judgment of the Portuguese Constitutional Court, of $14^{\text {th }}$ August 2014, no $.574 / 2014$. para. 12.
} 
contributes to the progress of European Constitutional Law itself. From this open and flexible understanding of the national constitutional identity, we may build convergence processes, both in the European and national spheres, that favour the evolution in Europeist terms of the national constitutional law and the progressive transformation in constitutional terms of the European legal system. 